\title{
Peran Pendidikan Dalam Membangun Karakter Bangsa Yang Bermoral
}

\author{
Inanna \\ Pendidikan Ekonomi Universitas Negeri Makassar \\ Email: inanna@unm.ac.id
}

\begin{abstract}
This paper is a scientific idea that aims to give an idea of the importance of building the character of moral human resources, through the internalization of positive values in the implementation of education. This is one way to be able to overcome various issues, especially moral decadence among young people. The method used is literature review. In general, the values that need to be developed and internalized in the implementation of education in Indonesia, among others, religious, mutual cooperation, togetherness, humility, refinement, hospitality, tolerance, so that the unity and unity of the nation can be realized.
\end{abstract}

Keywords: Nation Character, Moral Decadence, Moral Education

\begin{abstract}
Abstrak. Tulisan ini merupakan gagasan ilmiah yang bertujuan untuk memberikan gambaran akan pentingnya membangun karakter sumber daya manusia yang bermoral, melalui internalisasi nilai-nilai positif dalam penyelenggaraan pendidikan. Hal tersebut merupakan salah satu cara untuk bisa mengatasi berbagai persoalan khususnya dekadensi moral dikalangan generasi muda. Metode yang digunakan adalah kajian kepustakaan. Secara umum, nilai-nilai yang perlu untuk terus dikembangkan dan diinternalisasikan dalam pelaksanaan pendidikan di Indonesia antara lain religius, gotong royong, kebersamaan, rendah hati, kehalusan budi, ramah-tamah, toleransi, sehingga dapat terwujud persatuan dan kesatuan bangsa.
\end{abstract}

Kata Kunci: Karakter Bangsa, Dekadensi Moral, Pendidikan Moral

\section{PENDAHULUAN}

Perlu disadari bahwa kita berada di tanah Indonesia yang dikaruniai kekayaan alam, kekayaan budaya dan jumlah penduduk yang cukup besar. Dari sinilah kita mulai melihat ke dunia luar dan bukan sebaliknya. Kita berpijak di bumi Indonesia dan kita dapat melihat ke dunia luar untuk kepentingan kita. Oleh sebab itu merupakan kewajiban kita untuk tetap menghormati dan mengembangkan nilai-nilai yang menjadi karakter bangsa Indonesia seperti gotong royong, kebersamaan, rendah hati, kehalusan budi, ramah-tamah, toleransi yang harus terus menerus dijaga dan dikembangkan untuk menjaga kesatuan bangsa Indonesia.

Demikian pula dengan tegas kita menolak nilai-nilai negatif yang lahir dari adanya perkembagan perekonomian global yang senantiasa menggiring manusia untuk lebih bersifat egois dalam arti lebih bersifat individualistik, materialistik dan berujung pada ciri kehidupan yang hedonis. Memegang teguh karakter bangsa Indonesia akan menjadikan kita bangsa yang maju, berdaulat, adil, makmur dan bermartabat.

Berbagai masalah nasional yang dihadapi begitu kompleks dan tidak kunjung selesai. Misalnya aspek politik, di mana masalahnya mencakup kerancuan sistem ketatanegaraan dan pemerintahan, kelembagaan Negara yang tidak efektif, sistem kepartaian yang tidak mendukung, dan berkembangnya pragmatism politik. Lalu aspek ekonomi, masalahnya meliputi paradigm ekonomi yang tidak konsisten, struktur ekonomi dualistis, kebijakan fiskal yang belum mandiri, sistem keuangan dan perbankan yang tidak memihak, dan kebijakan perdagangan dan industri yang liberal. Dan aspek sosial budaya, masalah yang terjadi saat ini adalah memudarnya rasa dan ikatan kebangsaan, disorientasi nilai keagamaan, 
Inanna, Peran Pendidikan Dalam Membangun... $\mid 28$

memudarnya kohesi dan integrasi sosial, dan melemahnya mentalitas positif.

Dari sejumlah fakta positif atas modal besar yang dimiliki bangsa Indonesia, jumlah penduduk yang besar menjadi modal yang paling penting karena kemajuan dan kemunduran suatu bangsa sangat bergantung pada faktor manusianya (SDM). Masalah-masalah politik, ekonomi, dan sosial budaya juga dapat diselesaikan dengan SDM. Namun untuk menyelesaikan masalah-masalah tersebut dan menghadapi berbagai persaingan peradaban yang tinggi untuk menjadi Indonesia yang lebih maju diperlukan revitalisasi dan penguatan karakter SDM yang kuat. Salah satu aspek yang dapat dilakukan untuk mempersiapkan karakter SDM yang kuat adalah melalui pendidikan.

Pendidikan merupakan upaya yang terencana dalam proses pembimbingan dan pembelajaran bagi individu agar berkembang dan tumbuh menjadi manusia yang mandiri, bertanggungjawab, kreatif, berilmu, sehat, dan berakhlak mulia baik dilihat dari aspek jasmani maupun ruhani. Manusia yang berakhlak mulia, yang memiliki moralitas tinggi sangat dituntut untuk dibentuk atau dibangun. Bangsa Indonesia tidak hanya sekedar memancarkan kemilau pentingnya pendidikan, melainkan bagaimana bangsa Indonesia mampu merealisasikan konsep pendidikan dengan cara pembinaan, pelatihan dan pemberdayaan SDM Indonesia secara berkelanjutan dan merata. Ini sejalan dengan Undang-undang No. 20 tahun 2003 tentang Sisdiknas yang mengatakan bahwa tujuan pendidikan adalah “.. agar menjadi manusia yang beriman dan bertakwa kepada Tuhan Yang Maha Esa, berakhlak mulia, sehat, berilmu, cakap, kreatif, mandiri, dan menjadi warga negara yang demokratis serta bertanggung jawab".

Melihat kondisi sekarang dan akan datang, ketersediaan SDM yang berkarakter merupakan kebutuhan yang amat vital. Ini dilakukan untuk mempersiapkan tantangan global dan daya saing bangsa. Memang tidak mudah untuk menghasilkan SDM yang tertuang dalam UU tersebut. Persoalannya adalah hingga saat ini SDM Indonesia masih belum mencerminkan cita-cita pendidikan yang diharapkan. Misalnya untuk kasus-kasus aktual, masih banyak ditemukan siswa yang menyontek di kala sedang menghadapi ujian, bersikap malas, tawuran antar sesama siswa, melakukan pergaulan bebas, terlibat narkoba, dan lain-lain. Di sisi lain, ditemukan guru, pendidik yang senantiasa memberikan contoh-contoh tidak baik ke siswanya. Kondisi ini terus terang sangat memilukan dan mengkhawatirkan bagi bangsa Indonesia yang telah merdeka sejak tahun 1945.

Kondisi ini mencerminkan masalah moral yang memainkan peran cukup sgnifikan yang mengharuskan adanya tindakan-tindakan untuk mengatasinya. Jawaban yang paling kompleks yaitu melalui pendidikan baik formal, informal maupun non formal, sebagai upaya untuk membangun karakter SDM yang bermoral sehingga mampu membentuk pribadi yang kuat dan tangguh dalam menghadapi persaingan yang semakin ketat dimasa yang akan datang.

\section{PEMBAHASAN}

A. Pentingnya Pendidikan.

Disadari atau tidak, pendidikan merupakan hal terpenting untuk membentuk kepribadian. Pendidikan itu tidak selalu berasal dari pendidikan formal seperti sekolah atau perguruan tinggi. Pendidikan informal dan non formal pun memiliki peran yang sama untuk membentuk kepribadian, terutama anak atau peserta didik. Dalam UU Sisdiknas No. 20 tahun 2003 kita dapat melihat ketiga perbedaan model lembaga pendidikan tersebut. Dikatakan bahwa Pendidikan formal adalah jalur pendidikan yang terstruktur dan berjenjang yang terdiri atas pendidikan dasar, pendidikan menengah, dan pendidikan tinggi. Sementara pendidikan nonformal adalah jalur pendidikan di luar pendidikan formal yang dapat dilaksanakan secara terstruktur dan berjenjang. Satuan pendidikan nonformal terdiri atas lembaga kursus, lembaga pelatihan, kelompok belajar, pusat kegiatan belajar masyarakat, dan majelis taklim, serta satuan pendidikan yang sejenis. Sedangkan pendidikan informal adalah jalur pendidikan keluarga dan lingkungan. Kegiatan pendidikan informal dilakukan oleh keluarga dan lingkungan dalam bentuk kegiatan belajar secara mandiri.

Memperhatikan ketiga jenis pendidikan di atas, ada kecenderungan bahwa pendidikan formal, pendidikan informal dan pendidikan non formal yang selama ini berjalan terpisah satu dengan yang lainnya. Mereka tidak saling mendukung untuk peningkatan pembentukan kepribadian peserta didik. Setiap lembaga pendidikan tersebut berjalan masing-masing sehingga yang terjadi sekarang adalah pembentukan pribadi peserta didik menjadi parsial, misalnya anak bersikap baik di rumah, namun ketika keluar rumah atau berada di 
sekolah ia melakukan perkelahian antarpelajar, memiliki 'ketertarikan' bergaul dengan WTS atau melakukan perampokan. Sikap-sikap seperti ini merupakan bagian dari penyimpangan moralitas dan prilaku sosial pelajar (Suyanto, 2000).

Oleh karena itu, dalam rangka membangun dan melakukan penguatan peserta didik perlu menyinergiskan ketiga komponen lembaga pendidikan. Upaya yang dapat dilakukan salah satunya adalah pendidik dan orangtua berkumpul bersama mencoba memahami gejala-gejala anak pada fase negatif, yang meliputi keinginan untuk menyendiri, kurang kemauan untuk bekerja, mengalami kejenuhan, ada rasa kegelisahan, ada pertentangan sosial, ada kepekaan emosional, kurang percaya diri, mulai timbul minat pada lawan jenis, adanya perasaan malu yang berlebihan, dan kesukaan berkhayal (Mappiare dalam Suyanto, 2000). Dengan mempelajari gejala-gejala negatif yang dimiliki anak remaja pada umumnya, orangtua dan pendidik akan dapat menyadari dan melakukan upaya perbaikan perlakuan sikap terhadap anak dalam proses pendidikan formal, non formal dan informal.

B. Pentingnya Pendidikan Moral bagi Peserta Didik

Kata moral berasal dari bahasa latin mores yang berarti tata cara dalam kehidupan atau adat istiadat. Budiningsih, (2008) berpendapat bahwa penalaran moral menekankan pada alasan mengapa suatu tindakan dilakukan, sehingga dapat dinilai apakah tindakan tersebut baik atau buruk. Semakin menurunnya moral di kalangan remaja dianggap sebagai cerminan akan kurang berhasilnya dunia pendidikan di era globalisasi dewasa ini. Namun itu perlu di buktikan kebenarannya, karena pendidikan moral tidak hanya diperoleh dilingkungan sekolah, melainkan dilingkungan keluargalah awal pendidikan moral terhadap anak mulai ditanamkan.

Mulyani, dkk. (2007) menyatakan bahwa anak-anak akan mengidentifikasi dirinya dengan ibu atau ayahnya serta orang lain yang dekat dengannya. Dasar pendidikan agama yang kokoh jika ditanamkam pada anak sedini mungkin akan membentuk karakter penuh kasih dan peduli terhadap sesama.Hal ini bisa terjadi karena setiap agama pasti akan memberikan pelajaran budi pekerti dan akhlak mulia. dari uraian tersebut dapat disimpulkan bahwa keluarga sangat berperan dalam pembentukan moral anak.

Di bidang pendidikan sekolah, terjadinya penyimpangan-penyimpangan moral peserta didik merupakan tanggung jawab semua pendidik dalam membentuk moralitas peserta didik. Sigit, dkk. (2007) menyatakan bahwa Pendidikan moral di sekolah diharapkan dapat menghasilkan peserta didik yang memiliki kompetensi personal dan sosial sehingga menjadi warga negara yang baik karena sumber daya manusia yang akan datang adalah anakanak dan generasi muda masa kini.

Berbicara mengenai pendidikan moral di Indonesia, maka pemerintah zaman Orde Baru, pendidikan moral dikaitkan dengan nilai-nilai dasar Pancasila. Hal ini dimaksudkan bahwa sebagai dasar negara, maka kedudukan Pancasila merupakan landasan dan falsafah hidup dalam berbangsa dan bernegara. Karena itu, pendidikan moral ditanamkan pada peserta didik melalui pemberian mata pelajaran yang diberi nama Pendidikan Moral Pancasila (PMP) yang kemudian berubah menjadi Pendidikan Pancasila dan Kewarganegaraan (PPKn). Pentingnya pendidikan moral ini, sehingga ia menjadi mata pelajaran istimewa di samping mata pelajaran pendidikan agama. Pada waktu itu apabila peserta didik memperoleh nilai rendah pada kedua mata pelajaran tersebut, menjadi bahan pertimbangan apakah seseorang naik atau tinggal kelas. Bahkan proses penilaian atas mata pelajaran khusus pendidikan moral ini, tidak hanya dilihat dari aspek kognitif semata. Sebaliknya, tingkah laku peserta didik dengan berbagai standar nilai yang telah ditetapkan menjadi indikator penentu. Pada waktu itu guru agama dan guru PMP pun sangat dihormati karena dianggap sebagai penentu nasib para peserta didik. Tapi masa reformasi sekarang kedua mata pelajaran yang dahulu dianggap maha penting, kini tampak kurang menjadi prioritas serta menjadi korban kebijakan kurikulum.

Menghadapi krisis moral yang sedang melanda bangsa ini, maka sudah seharusnya Pendidikan mengambil peranan sebagai benteng moral bangsa. Menurut Ki Hajar Dewantara, pendidikan merupakan daya upaya untuk memajukan bertumbuhnya budi pekerti (kekuatan batin, karakter), pikiran (intellect), dan tubuh anak. Selain itu dalam UU Sisdiknas juga dituliskan bahwa "Pendidikan nasional berfungsi mengembangkan kemampuan dan membentuk watak serta peradaban bangsa yang 
bermartabat dalam rangka mencerdaskan kehidupan bangsa, bertujuan untuk berkembangnya potensi peserta didik agar menjadi manusia yang beriman dan bertakwa kepada Tuhan Yang Maha Esa, berakhlak mulia, sehat, berilmu, cakap, kreatif, mandiri, dan menjadi warga negara yang demokratis serta bertanggung jawab".

Hal itu menunjukkan betapa pentingnya pendidikan moral dan pembangunan karakter bangsa. Pendidikan moral merupakan bagian integral yang sangat penting dari pendidikan kita. Untuk itu dunia pendidikan harus mampu menjadi motor penggerak untuk memfasilitasi pembangunan moral bangsa, sehingga setiap peserta didik mempunyai kesadaran kehidupan berbangsa dan bernegara yang harmonis dan demokratis dengan tetap memperhatikan sendisendi NKRI dan norma-norma sosial di masyarakat yang telah menjadi kesepakatan bersama.

Pendidikan moral sebagai bagian dari pendidikan nilai di sekolah, yang membantu peserta didik mengenal, menyadari pentingnya, nilai-nilai moral yang seharusnya dijadikan panduan bagi sikap dan perilakunya sebagai manusia, baik secara perorangan maupun bersama-sama dalam suatu masyarakat. Nilai moral mendasari prinsip dan norma hidup baik yang memandu sikap dan perilaku manusia sebagai pedoman dalam hidupnya. Kita semua tentu mengetahui, kualitas hidup seseorang ditentukan oleh nilai-nilai, dan termasuk di dalamnya yaitu nilai moral.

Watak dan kepribadian seseorang dibentuk oleh nilai-nilai yang dipilih, diusahakan, dalam setiap tindakan-tindakannya. Dalam upaya pengenalan dan penyadaran pentingnya penghayatan nilai-nilai moral, pendidikan moral memuat unsur penyampaian pengetahuan moral kepada peserta didik, serta pengembangan pengetahuan moral yang sudah ada padanya.

Pendidikan moral yang ada di sekolah saat ini seolah terkesan hanya menginformasikan teori-teori dan pengetahuan konsep moral kepada peserta didik, sehingga pendidikan moral yang ada saat ini belum mampu membuat perubahan perilaku pada peserta didik. Hal ini ditunjukkan semakin maraknya isu-isu moral yang negatip di kalangan generasi muda dewasa ini.
C. Pengaruh
Globalisasi
terhadap
Perkembangan Moral Peserta didik

Perkembangan Teknologi dan Informasi merupakan factor pendukung utama arus globalisasi. Perkembangan teknologi dewasa ini begitu cepat sehingga segala informasi dengan berbagai bentuk dapat tersebar luas ke seluruh dunia. Oleh karena itu globalisasi tidak dapat kita hindari kehadirannya. Akibat globalisasi tentunya membawa pengaruh terhadap suatu negara termasuk Indonesia, khususnya terhadap perkembangan moral peserta didik

Pengaruh negatif globalisasi yang berkaitan dengan perkembangan moral peserta didik antara lain dalam bidang budaya dan sosial, banyak dikalangan remaja telah hilang nilai-nilai nasionalisme bangsa kita, misalnya sudah tidak kenal sopan santun, cara berpakaian, dan gaya hidup mereka cenderung meniru budaya barat. Munculnya sikap individualisme, kurang peduli terhadap orang lain sehingga sikap gotong royong semakin luntur. Oleh karena itu, perlu dilakukan langkah-langkah untuk mengantisipasi pengaruh negatif arus globalisasi terhadap nilai-nilai nasionalisme bangsa kita, khususnya terhadap perkembangan moral peserta didik. Langkah-langkah untuk mengantisipasi pengaruh negatif arus globalisasi perkembangan moral peserta didik antara lain:

1. Menanamkan sikap kepada peserta didik untuk mencintai produk dalam negeri melalui pembelajaran di sekolah

2. Menumbuhkembangkan nilai-nilai Pancasila yang merupakan dasar negara kita terhadap peserta didik

3. Menanamkan dan melaksanakan ajaran agama tidak hanya tanggung jawab guru agama, melainkan merupakan tanggung jawab oleh semua guru bidang studi

4. Menginformasikan kepada peserta didik untuk menyeleksi arus globalisasi dalam segala bidang, melalui pembelajaran.

Dengan cara mengantisipasi pengaruh negatif arus globalisasi terhadap perkembangan moral peserta didik, maka diharapkan peserta didik nantinya akan terhindar dari budaya barat yang tidak relevan dengan nilai-nilai nasionalisme dan cita-cita luhur bangsa kita yang telah digariskan dalam Undang-Undang Negara Republik Indonesia

\section{Membangun Sumber Daya Manusia} Berkarakter Di Era Globalisasi

SDM merupakan aset paling penting untuk membangun bangsa yang lebih baik dan maju. Namun untuk mencapai itu, SDM yang kita miliki harus berkarakter. SDM yang berkarakter kuat dicirikan oleh kapasitas mental 
yang berbeda dengan orang lain seperti keterpercayaan, ketulusan, kejujuran, keberanian, ketegasan, ketegaran, kekuatan dalam memegang prinsip, dan sifat-sifat unik lainnya yang melekat dalam dirinya.

Secara lebih rinci, beberapa konsep tentang manusia Indonesia yang berkarakter dan senantiasa melekat dengan kepribadian bangsa. Ciri-ciri karakter SDM yang kuat meliputi (1) religious, yaitu memiliki sikap hidup dan kepribadian yang taat beribadah, jujur, terpercaya, dermawan, saling tolong menolong, dan toleran; (2) moderat, yaitu memiliki sikap hidup yang tidak radikal dan tercermin dalam kepribadian yang tengahan antara individu dan sosial, berorientasi materi dan ruhani serta mampu hidup dan kerjasama dalam kemajemukan; (3) cerdas, yaitu memiliki sikap hidup dan kepribadian yang rasional, cinta ilmu, terbuka, dan berpikiran maju; dan (4) mandiri, yaitu memiliki sikap hidup dan kepribadian merdeka, disiplin tinggi, hemat, menghargai waktu, ulet, wirausaha, kerja keras, dan memiliki cinta kebangsaan yang tinggi tanpa kehilangan orientasi nilai-nilai kemanusiaan universal dan hubungan antarperadaban bangsa-bangsa (PP Muhammadiyah, 2009).

Tidak dapat dipungkiri, arus globalisasi begitu cepat merasuk ke dalam masyarakat terutama di kalangan remaja. Pengaruh globalisasi terhadap anak muda begitu kuat. Pengaruh globalisasi tersebut telah membuat banyak anak muda kita kehilangan kepribadian diri sebagai bangsa Indonesia. Hal ini ditunjukkan dalam kehidupan sehari-hari, misalnya dalam cara berpakaian, selera makan. Yang lebih memprihatinkan adalah pergaulan bebas antar remaja.

Pada Era globalisasi dewasa ini dekadensi moral tidak hanya terjadi di kalangan remaja saja, namun banyak terjadi pula dikalangan orang dewasa. Hal ini tidak bisa kita pungkiri lagi, ternyata di negeri tercinta yang berdasarkan Pancasila ini telah menodai nilainilai luhur dari Pancasila itu sendiri. Hal ini terbukti semakin maraknya korupsi oleh para pemimpin bangsa ini mulia dari level yang rendah sampai pada level yang tinggi.

Oleh karena itu, satu hal yang perlu untuk dipahami bahwa karakter tidak dapat dilepaskan dari konteks sosial budaya karena karakter terbentuk dalam lingkungan sosial budaya tertentu. Dalam hal ini para guru di sekolah dan orang tua harus saling mengisi untuk menumbuhkan karakter positip pada anak melalui pembelajaran yang berkaitan dengan pendidikan agama sehingga generasi mendatang bangsa kita menjadi bangsa yang beriman berbudi pekerti luhur, berakhlak mulia.

E. Pentingnya Pendidikan Karakter Di Era Globalisasi

Berbicara pembentukan kepribadian tidak lepas dengan bagaimana kita membentuk karakter SDM. Pembentukan karakter SDM menjadi vital dan tidak ada pilihan lagi untuk mewujudkan Indonesia baru, yaitu Indonesia yang dapat menghadapi tantangan regional dan global (Muchlas dalam Sairin, 2001). Tantangan regional dan global yang dimaksud adalah bagaimana generasi muda kita tidak sekedar memiliki kemampuan kognitif saja, tapi aspek afektif dan moralitas juga tersentuh. Untuk itu, pendidikan karakter diperlukan untuk mencapai manusia yang memiliki integritas nilai-nilai moral sehingga anak menjadi hormat sesama, jujur dan peduli dengan lingkungan.

Lickona (1992) menjelaskan beberapa alasan perlunya Pendidikan karakter, di antaranya: (1) Banyaknya generasi muda saling melukai karena lemahnya kesadaran pada nilainilai moral, (2) Memberikan nilai-nilai moral pada generasi muda merupakan salah satu fungsi peradaban yang paling utama, (3) Peran sekolah sebagai pendidik karakter menjadi semakin penting ketika banyak anak-anak memperoleh sedikit pengajaran moral dari orangtua, masyarakat, atau lembaga keagamaan, (4) masih adanya nilai-nilai moral yang secara universal masih diterima seperti perhatian, kepercayaan, rasa hormat, dan tanggungjawab, (5) Demokrasi memiliki kebutuhan khusus untuk pendidikan moral karena demokrasi merupakan peraturan dari, untuk dan oleh masyarakat, (6) Tidak ada sesuatu sebagai pendidikan bebas nilai. Sekolah mengajarkan pendidikan bebas nilai. Sekolah mengajarkan nilai-nilai setiap hari melalui desain ataupun tanpa desain, (7) Komitmen pada pendidikan karakter penting manakala kita mau dan terus menjadi guru yang baik, dan (7) Pendidikan karakter yang efektif membuat sekolah lebih beradab, peduli pada masyarakat, dan mengacu pada performansi akademik yang meningkat.

Alasan-alasan di atas menunjukkan bahwa pendidikan karakter sangat perlu ditanamkan sedini mungkin untuk mengantisipasi berbagai persoalan akibat pengaruh globalisasi yang semakin kompleks seperti semakin rendahnya perhatian dan kepedulian anak terhadap lingkungan sekitar, 
tidak memiliki tanggungjawab, rendahnya kepercayaan diri, dan lain-lain.

Untuk mengetahui lebih jauh tentang apa yang dimaksud dengan pendidikan karakter, Lickona dalam Elkind (2004) menggagas pandangan bahwa pendidikan karakter adalah upaya terencana untuk membantu orang untuk memahami, peduli, dan bertindak atas nilai-nilai etika/ moral. Pendidikan karakter ini mengajarkan kebiasaan berpikir dan berbuat yang membantu orang hidup dan bekerja bersama-sama sebagai keluarga, teman, tetangga, masyarakat, dan bangsa.

Pandangan ini mengilustrasikan bahwa proses pendidikan yang ada di pendidikan formal, non formal dan informal harus mengajarkan peserta didik atau anak untuk saling peduli dan membantu dengan penuh keakraban tanpa diskriminasi karena didasarkan dengan nilai-nilai moral dan persahabatan. Di sini nampak bahwa peran pendidik dan tokoh panutan sangat membantu membentuk karakter peserta didik atau anak.

F. Peran Pendidik dalam Membentuk Karakter SDM

Pendidik itu bisa guru, orangtua atau siapa saja, yang penting ia memiliki kepentingan untuk membentuk pribadi peserta didik atau anak. Peran pendidik pada intinya adalah sebagai masyarakat yang belajar dan bermoral. Lickona, Schaps, dan Lewis (2007) serta Azra (2006) menguraikan beberapa pemikiran tentang peran pendidik, di antaranya:

1. Pendidik perlu terlibat dalam proses pembelajaran, diskusi, dan mengambil inisiatif sebagai upaya membangun pendidikan karakter

2. Pendidik bertanggungjawab untuk menjadi model yang memiliki nilai-nilai moral dan memanfaatkan kesempatan untuk mempengaruhi siswa-siswanya. Artinya pendidik di lingkungan sekolah hendaklah mampu menjadi "uswah hasanah" yang hidup bagi setiap peserta didik. Mereka juga harus terbuka dan siap untuk mendiskusikan dengan peserta didik tentang berbagai nilainilai yang baik tersebut.

3. Pendidik perlu memberikan pemahaman bahwa karakter siswa tumbuh melalui kerjasama dan berpartisipasi dalam mengambil keputusan

4. Pendidik perlu melakukan refleksi atas masalah moral berupa pertanyaanpertanyaan rutin untuk memastikan bahwa siswa-siswanya mengalami perkembangan karakter.

5. Pendidik perlu menjelaskan atau mengklarifikasikan kepada peserta didik secara terus menerus tentang berbagai nilai yang baik dan yang buruk.

Berdasarkan penjelasan di atas, maka peran pendidik di setiap jenis lembaga pendidikan dalam membentuk karakter siswa. Dalam pendidikan formal dan non formal, pendidik (1) harus terlibat dalam proses pembelajaran, yaitu melakukan interaksi dengan siswa dalam mendiskusikan materi pembelajaran, (2) harus menjadi contoh tauladan kepada siswanya dalam berprilaku dan bercakap, (3) harus mampu mendorong siswa aktif dalam pembelajaran melalui penggunaan metode pembelajaran yang variatif, (4) harus mampu mendorong dan membuat perubahan sehingga kepribadian, kemampuan dan keinginan guru dapat menciptakan hubungan yang saling menghormati dan bersahabat dengan siswanya, (5) harus mampu membantu dan mengembangkan emosi dan kepekaan sosial siswa agar siswa menjadi lebih bertakwa, menghargai ciptaan lain, mengembangkan keindahan dan belajar soft skills yang berguna bagi kehidupan siswa selanjutnya, dan (6) harus menunjukkan rasa kecintaan kepada siswa sehingga guru dalam membimbing siswa yang sulit tidak mudah putus asa.

Sementara dalam pendidikan informal seperti keluarga dan lingkungan, pendidik atau orangtua/tokoh masyarakat (1) harus menunjukkan nilai-nilai moralitas bagi anakanaknya, (2) harus memiliki kedekatan emosional kepada anak dengan menunjukkan rasa kasih sayang, (3) harus memberikan lingkungan atau suasana yang kondusif bagi pengembangan karakter anak, dan (4) perlu mengajak anak-anaknya untuk senantiasa mendekatkan diri kepada Allah, misalnya dengan beribadah secara rutin. Berangkat dari upaya-upaya yang pendidik lakukan, maka diharapkan akan tumbuh dan berkembang SDM yang berkarakter dan bermoral yang memiliki kemampuan unggul dalam menghadapi globalisasi.

\section{SIMPULAN}

Untuk menjadi bangsa yang maju dan bermartabat ditengah perkembangan perekonomian global yang sangat pesat 
sangatlah tergantung pada faktor manusianya atau kualitas sumber daya manusia (SDM) yang dimiliki bangsa Indonesia. Oleh karena itu, salah satu cara untuk bisa mengatasi berbagai persoalan yang terjadi baik persoalan politik, ekonomi, dan social, budaya serta masalah dekadensi moral khususnya dikalangan para pelajar, maka dibutuhkan penguatan karakter SDM yang kuat yang didasarkan pada karakter bangsa indonesia melalui berbagai jenis pendidikan (formal, informal dan non formal) serta pada berbagai jenjang pendidikan (mulai dari pendidikan dasar, menengah, dan perpendidikan tinggi).

\section{DAFTAR RUJUKAN}

Asri, B, (2008). Pembelajaran Moral. Jakarta: PT Rineka Cipta

Darmiyati, Tri. Pengaruh Globalisasi terhadap Nilai-Nilai Nasionalisme. http://www.wikimu.com/News/DisplayN ews.aspx?id=7124

Edi Subkhan, mahasiswa Program Pascasarjana, S2 Universitas Negeri Jakarta dalam http://edukasi.kompasiana.com/2010/05/ 23/mari-membangun-karakter-bangsamelalui-olah-pikir-olah-hati-olah-ragaolah-rasa-dan-karsal

Hamid, M, (2008). Peran serta Guru Profesional dalam Turut Membentuk karakter bangsa Melalui Jalur Pendidikan Nonformal dan Informal. Jakarta: disajikan dalam Seminar nasional

Lickona, Tom; Schaps, Eric, dan Lewis, Catherine (2007). Eleven Principles of Effective Character Education. Character Education Partnership.

Munir, (2010). Pendidikan Karakter. Yogyakarta: PT Pustaka Insan Maqdani, Anggota IKPI

Pimpinan Pusat Muhammadiyah (2009). Revitalisasi Visi dan Karakter Bangsa. Yogyakarta: PP Muhammadiyah

Wardani. 2008. Pendidikan sebagai Wahana Pembentukan Karakter Bangsa. Jakarta: disajikan dalam Seminar nasional

Wardoyo, Cipto.2007. Urgensi Pendidikan Moral pada (http://www.nu.or.id 